LWSA

PAPER - OPEN ACCESS

Pengaruh Kesulitan Keuangan, Pergantian Dewan Komisaris, Opiniaudit, Reputasi Auditor, Audit Tenure, Biaya Audit terhadap Auditor Switching pada Perusahaan Manufaktur yang Terdaftar di BEI Periode 2011-2014

\author{
Author : Firman Syarif \\ DOI $\quad: 10.32734 /$ lwsa.v1i1.137 \\ Electronic ISSN : :2654-7058 \\ Print ISSN : :2654-7066
}

Volume 1 Issue 1 - 2018 TALENTA Conference Series: Local Wisdom, Social and Arts

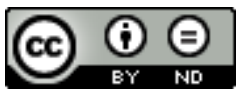

This work is licensed under a Creative Commons Attribution-NoDerivatives 4.0 International License.

Published under licence by TALENTA Publisher, Universitas Sumatera Utara
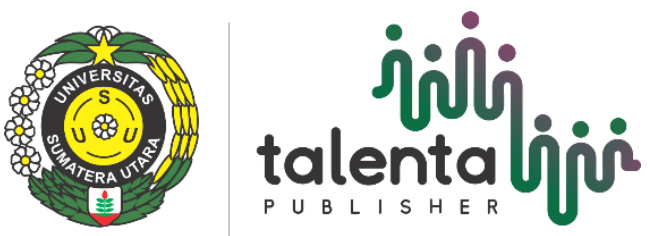


\title{
Pengaruh Kesulitan Keuangan, Pergantian Dewan Komisaris, Opiniaudit, Reputasi Auditor, Audit Tenure, Biaya Audit terhadap Auditor Switching pada Perusahaan Manufaktur yang Terdaftar di BEI Periode 2011-2014
}

\author{
Firman Syarif ${ }^{\mathrm{a}}$, Kristina Hasibuan ${ }^{\mathrm{b}}$ \\ ${ }^{a}$ Fakultas Ekonomi dan Bisnis, Universitas Sumatera Utara, Medan-20155, Indonesia \\ ${ }^{b}$ Departemen AkuntansiUniversitas Sumatera Utara, Medan-20155 , Indonesia \\ brandan_firman@yahoo.com,kristina_hasibuan@yahoo.co.id
}

\begin{abstract}
Abstrak
Penelitian ini bertujuan untuk menganalisis pengaruh dari kesulitan keuangan, pergantian dewan komisaris, opini audit, reputasi auditor, audit tenure, biaya audit terhadap auditor switching pada perusahaan manufaktur yang terdaftar di Bursa Efek Indonesia antara tahun 2011 hingga 2014. Populasi penelitian ini sebanyak 142 perusahaan Manufaktur yang terdaftar di Bursa Efek Indonesia. Metode pengambilan sampel yang digunakan adalah metode purposive sampling, sehingga diperoleh 39 perusahaan sampel untuk 4 tahun pengamatan (2011-2014) dengan 156 unit analisis. Jenis data yang digunakan oleh peneliti adalah data sekunder. Data penelitian ini diperoleh dari laporan tahunan yang telah diaudit dan yang diunduh dari website BEI yaitu $w w w . i d x . c o . i d . P e n g o l a h a n$ data dilakukan dengan program bantuan program SPSS 22 dengan teknik analisis data metode regresi logistik. Hasil penelitian ini menunjukkan bahwa secara parsial audit tenure berpengaruh secara signifikan terhadap auditor switching, sedangkan kesulitan keuangan, pergantian dewan komisaris, opini audit, reputasi auditor dan biaya audit tidak berpengaruh secara signifikan terhadap auditor switching. Secara simultan, hasil penelitian menunjukkan bahwa kesulitan keuangan, pergantian dewan komisaris, opini audit, reputasi auditor, audit tenure dan biaya audit berpengaruh secara signifikan terhadap auditor switching.
\end{abstract}

Kata kunci: Kesulitan keuangan; pergantian dewan komisaris; opini audit, reputasi auditor; audit tenure; biaya audit; auditor switching

\section{Pendahuluan}

Auditor switching menurut Wijayanti (2010) adalah pergantian auditor (KAP) yang dilakukan oleh perusahaan klien. Auditor Switching dapat bersifat wajib (mandatory) ataupun sukarela (voluntary). Perusahaan yang melakukan pergantian Kantor Akuntan Publik secara mandatory seperti Peraturan Menteri Keuangan Republik Indonesia Nomor 17/PMK.01/2008 pasal 3 tentang Jasa Akuntan Publik yang membahas lamanya pemberian jasa audit umum yang dilakukan oleh KAP maupun seorang akuntan. Sedangkan perusahaan yang melakukan pergantian Kantor Akuntan Publik secara voluntary disebabkan karena Kantor Akuntan Publik yang tidak sejalan dengan kepentingan manajemen perusahaan, sehingga perusahaan melakukan pergantian auditor secara voluntary. 
Auditor adalah pihak independen yang diharapkan dapat menjembatani benturan kepentingan antara pihak prinsipal (pemegang saham) dengan pihak agen, yaitu manajemen sebagai pengelola perusahaan. Dalam hal ini, peran auditor adalah memberi opini terhadap kewajaran laporan keuangan yang disajikan perusahaan. Laporan keuangan disusun oleh pihak manajemen perusahaan sebagai gambaran atas kinerja selama suatu periode waktu. Laporan keuangan menurut Nurzaimah dan Syahrul (2010: 3) adalah "hasil dari proses akuntansi yang dapat memberikan informasi tentang keadaan suatu perusahaan sekaligus merupakan alat komunikasi antara data keuangan dan aktivitas pe rusahaan dengan pihak-pihak yang berkepentingan dengan data atau aktivitas perusahaan tersebut."

Laporan keuangan menyediakan berbagai informasi yang diperlukan untuk pengambilan keputusan baik oleh pihak internal maupun eksternal.Laporan keuangan yang disusun pihak manajemen berpotensi dipengaruhi kepentingan pribadi, sementara pihak eksternal selaku pemakai laporan keuangan sangat berkepentingan untuk mendapatkan laporan keuangan yang dapat dipercaya.Karenanya dibutuhkan akuntan publik sebagai pihak yang bisa menjamin kualitas dari laporan tersebut.Akuntan publik harus bersikap independen, artinya tidak mudah dipengaruhi dan tidak dibenarkan memihak kepada kepentingan siapa pun.

Independensi dibutuhkan untuk menambah keandalan dan kredibilitas pelaporan keuangan. Namun, Nasser et al. (2006) menyatakan hubungan yang panjang dapat menyebabkan auditor memiliki kecenderungan kehilangan independensinya. Auditor yang memiliki hubungan yang lama dengan klien diyakini akan membawa ketergantungan tinggi antara auditor dengan klien. Hal ini berawal dari skandal Enron pada tahun 2001, yang melakukan kerja sama dengan KAP Arthur Andersen dengan cara memanipulasi laba perusahaan. Laba dalam laporan keuangan Enron dicatat terlalu besar (overstated) oleh staf akuntan Enron yang merupakan mantan auditor di KAP Arthur Andersen, sementara KAP Arthur Andersen menjadi auditor eksternal atas laporan keuangan tersebut. Enron diaudit oleh Kantor Akuntan Publik Arthur Andersen selama 16 tahun sejak 1985.Hal ini terjadi akibat adanya hubungan kerja yang panjang antara KAP dan klien yang memungkinkan menciptakan suatu resiko excessive familiarity (berlebihan keakraban) yang mempengaruhi independensi KAP.

Hal yang sama terjadi di Indonesia. PT BAT Indonesia hanya memiliki satu auditor yaitu kantor akuntan yang sama dengan berafiliasi ke PWC sekarang ini, walaupun KAP tersebut berganti nama beberapa kali sejak tahun 1979 hingga 2004. Artinya, selama 25 tahun mereka tidak pernah mengganti auditor.

Hal yang sama terjadi juga pada PT Aqua Golden Mississippi. Perusahaan ini diaudit oleh KAP Utomo dan KAP Prasetio Utomo yang mana kedua KAP ini adalah KAP yang sama sejak tahun 1989 -2001. Tahun 2002 mereka pindah ke KAP Prasetio, Sarwoko, dan Sanjaya.KAP ini adalah kelanjutan dari KAP Prasetio Utomo yang bubar dan menggabungkan diri ke KAP Sarwoko dan Sanjaya.Sebagian orang berpendapat bahwa KAP yang baru ini (yang berafiliasi ke Ernst \& Young) adalah kelanjutan dari KAP yang pertama (Arthur Andersen). Sehingga, bisa dikatakan bahwa selama 14 tahun PT Aqua diaudit oleh satu KAP.

Untuk menjaga kepentingan publik, auditor tidak diperbolehkan memiliki hubungan pribadi dengan klien mereka yang mungkin dapat menimbulkan terjadinya konflik dalam kepentingan. Salah satu saran yang dapat dilakukan untuk meminimalisir munculnya kasus-kasus serupa adalah dengan memberlakukan auditor switching secara mandatory.

Namun, ada fenomena yang berbeda terjadi. Beberapa perusahaan melakukan auditor switching secara voluntary. Auditor Switching secara voluntary disebabkan oleh dua hal yaitu auditor dipecat oleh kliennya atau auditor mengundurkan diri. Peneliti memperhatikan hubungan klien dengan auditor karena apabila hubungan keduanya berjalan normal maka tidak mungkin klien akan melakukan auditor switching secara voluntary.

Peneliti memilih variabel kesulitan keuangan, pergantian dewan komisaris, opini audit, reputasi auditor, audit tenure, dan biaya audit sebagai variabel yang mempengaruhi terjadinya auditor switching. Terdapat perbedaan hasil penelitian yang dilakukan beberapa peneliti terhadap auditor switching. Hasil penelitian yang berbeda-beda tersebut juga memotivasi peneliti untuk meneliti kembali faktor-faktor yang mempengaruhi auditor switching pada perusahaan manufaktur yang terdaftar di BEI. 


\section{Pengembangan hipotesis}

\subsection{Hubungan antara kesulitan keuangan dan auditor switching}

Kesulitan keuangan merupakan kondisi perusahaan yang sedang dalam keadaan tidak sehat atau sedang krisis keuangan. Perusahaan yang mengalami kesulitan keuangan lebih sering berpindah KAP daripada perusahaan yang tidak mengalami kesulitan keuangan. Ada dorongan yang kuat untuk berpindah auditor pada perusahaan yang terancam bangkrut. Auditor switching salah satunya disebabkan karena perusahaan sudah tidak memiliki kemampuan untuk membayar biaya audit yang dibebankan oleh KAP yang diakibatkan penurunan kemampuan keuangan perusahaan. [32].

Hudaib da Cooke (2005) menyatakan bahwa klien dengan tekanan finansial cenderung untuk menggantikan KAP mereka dibandingkan dengan rekan-rekan mereka yang lebih sehat. Oleh karena itu, kesulitan keuangan dapat mempengaruhi terjadinya pergantian auditor.

Berdasarkan penjelasan diatas, maka hipotesis penelitiannya adalah:

H1: Kesulitan keuangan berpengaruh terhadap auditor switching.

\subsection{Hubungan antara pergantian dewan komisaris dan auditor switching}

UU Nomor 40 Tahun 2007 tentang Perseroan Terbatas disebutkan bahwa Dewan Komisaris bertugas untuk melakukan pengawasan dan memberi nasihat kepada Direksi mengenai Perseroan maupun Usaha Perseroan. Dalam hal melakukan pengawasan terhadap Perseroan dan Usaha Perseroan, Dewan Komisaris berkewenangan mengangkat KAP melalui komite audit. Karena Dewan Komisaris berkewenangan mengangkat KAP, sehingga apabila terjadi pergantian terhadap Dewan Komisaris, maka pergantian ini kemungkinan akan menimbulkan pergantian KAP.

Berdasarkan penjelasan diatas, maka hipotesis penelitiannya adalah:

H2: Pergantian dewan komisaris berpengaruh terhadap auditor switching.

\subsection{Hubungan antara opini audit dan auditor switching}

Opini audit didefinisikan sebagai pendapat yang dikeluarkan oleh auditor untuk menilai kewajaran laporan keuangan. Menurut Sembiring (2015) opini audit yang dikeluarkan oleh auditor biasanya mempengaruhi perusahaan dalam menetapkan apakah perusahaan akan tetap memakai jasa kantor akuntan publik tersebut atau menggantinya. Hal ini disebabkan karena perusahaan mengharapkan opini yang dikeluarkan oleh auditor ialah opini wajar tanpa pengecualian (unqualified opinion). Jika perusahaan mendapatkan opini audit diluar opini wajar tanpa pengecualian dari auditor, maka perusahaan cenderung akan melakukan auditor switching.

Berdasarkan penjelasan diatas, maka hipotesis penelitiannya adalah:

H3: Opini Audit berpengaruh terhadap auditor switching.

\subsection{Hubungan antara reputasi auditor dan auditor switching}

Reputasi auditor merupakan prestasi dan kepercayaan publik yang disandang auditor atas nama besar yang dimiliki auditor tersebut. Manajer akan memilih KAP yang memiliki reputasi sebagai bagian dari strategi membangun reputasi atas kredibilitas laporan keuangan Auditor yang memiliki reputasi diproksikan dengan KAP Big 4. KAP yang bereputasi dipandang akan melaksanakan proses audit dengan lebih berkualitas dibandingkan dengan KAP yang lain. Praptitorini dan Januarti (2007) menyatakan bahwa Perusahaan yang sudah menggunakan KAP yang bereputasi tidak akan melakukan auditor switching karena investor lebih percaya pada laporan keuangan auditan yang dihasilkan oleh auditor yang bereputasi. Sedangkan perusahaan yang menggunakan KAP NonBig 4 cenderung melakukan auditor switching. 
Berdasarkan penjelasan diatas, maka hipotesis penelitiannya adalah:

H4: Reputasi Auditor berpengaruh terhadap auditor switching

\subsection{Hubungan antara audit tenure dan auditor switching}

Audit tenure diartikan sebagai periode keterikatan antara auditor/KAP dengan klien, yaitu lamanya auditor/KAP mengaudit pada perusahaan klien. Independensi auditor/KAP akan terganggu apabila ada hubungan yang lama antara auditor dengan klien akibat adanya kemungkinan keterikatan yang bersifat pribadi. Jenis perusahaan berdampak terhadap panjangnya audit tenure. Dengan kata lain bahwa perusahaan audit besar seperti Big 4 akan memiliki masa perikatan yang panjang dibandingkan dengan perusahaan audit yang kecil seperti non Big 4 . Kondisi ini berdampak pada perusahaan audit kecil yang akan kesulitan dalam menjaga keberlangsungan perusahaannya dalam kompetisi yang semakin memingkat dan ukuran yang tidak sebanding.

Berdasarkan penjelasan diatas, maka hipotesis penelitiannya adalah:

H5: Audit Tenure berpengaruh terhadap auditor switching.

\subsection{Hubungan antara biaya audit dan auditor switching}

Biaya audit merupakan honorarium atau upah yang dibebankan oleh akuntan publik kepada perusahaan auditee atas jasa audit yang dilakukan akuntan publik terhadap laporan keuangan. [22]. Dorongan untuk melakukan auditor switching dapat terjadi apabila biaya audit yang ditawarkan auditor relatif tinggi sehingga tidak ada terjadi kesepakatan antara perusahaan dengan KAP. Sejalan dengan Chadegoni et al. (2011) yang menyatakan bahwa ketika manajer tidak cocok dengan biaya audit, mereka akan mencoba mengganti KAP dengan penawaran yang lebih baik.

Berdasarkan penjelasan diatas, maka hipotesis penelitiannya adalah:

H6: Biaya Audit berpengaruh terhadap auditor switching.

\subsection{Hubungan antara kesulitan keuangan, pergantian dewan komisaris, opini audit, reputasi auditor, audit tenure,}

biaya audit secara bersama-sama dengan auditor switching

Pengaruh secara simultan digunakan untuk mengetahui apakah keenam variabel independen yaitu kesulitan keuangan, pergantian dewan komisaris, opini audit, reputasi auditor, audit tenure, biaya audit berpengaruh terhadap auditor switching.

H7: Kesulitan keuangan, pergantian dewan komisaris, opini audit, reputasi auditor, audit tenure, biaya audit berpengaruh terhadap auditor switching.

\section{Metode penelitian}

Jenis penelitian yang dilakukan adalah jenis penelitian sebab akibat (causal research). Tujuan penelitian ini adalah menguji hipotesis dan menjelaskan fenomena dalam bentuk hubungan antar variabel. Populasi dalam penelitian ini adalah 142 perusahaan manufaktur yang terdaftar di Bursa Efek Indonesia (BEI) pada tahun 2011 hingga 2014.

Metode penentuan sampel yang digunakan dalam penelitian ini adalah metode purposive sampling, yaitu metode pengambilan sampel berdasarkan suatu kriteria tertentu. Kriteria penentuan sampel dalam penelitian ini adalah:

- Perusahaan manufaktur yang terdaftar di Bursa Efek Indonesia (BEI) tahun 2011-2014. 
- Perusahaan yang mengeluarkan laporan tahunan secara lengkap untuk tahun 2011-2014, dan menyajikan informasi lengkap berupa informasi total hutang, total ekuitas, nama dewan komisaris, opini audit yang diberikan auditor, dan nama KAP.

- Perusahaan yang pernah mengalami pergantian KAP selama periode penelitian 2011-2014.

Berdasarkan kriteria tersebut, perusahaan yang menjadi sampel penelitian terdiri dari 39 perusahaan dengan periode penelitian selama 4 tahun, sehingga total unit analisis sebanyak 156 perusahaan.

Penelitian ini menggunakan uji analisis statistik deskriptif, analisis regresi logistik dan pengujian hipotesis penelitian yang terdiri dari menilai keseluruhan model, menguji kelayakan model regresi, koefisien determinasi, pengujian secara simultan.

\subsection{Variable penelitian}

\subsubsection{Variabel dependen}

Variabel dependen penelitian ini adalah auditor switching. Variabel auditor switching menggunakan variabel dummy. Jika perusahaan klien mengganti auditornya, maka diberikan nilai 1. Sedangkan jika perusahaan klien tidak mengganti auditornya, maka diberikan nilai 0 .

\subsubsection{Variable independen}

a. Kesulitan keuangan

Pengukuran kesulitan keuangan diukur dengan menggunakan DER (Debt to Equity Ratio). Adapun cara menghitung rasio DER adalah sebagai berikut:

$$
\text { DER }=\frac{\text { Total hutang }}{\text { Total ekuitas }}
$$

b. Penggantian dewan komisaris

Pengukuran pergantian dewan komisaris menggunakan variabel dummy. Jika perusahaan klien mengganti anggota dewan komisaris akan diberikan kode 1. Sedangkan jika perusahaan klien tidak mengganti anggota dewan komisaris, maka diberikan kode 0 .

c. Opini audit

Pengukuran variabel opini audit menggunakan variabel dummy. Jika perusahaan menerima opini wajar tanpa pengecualian (unqualified) maka diberi kode 1 sedangkan jika perusahaan menerima opini selain wajar tanpa pengecualian (unqualified) maka diberi kode 0 .

d. Reputasi auditor

Pengukuran variabel reputasi auditor menggunakan variabel dummy. Jika perusahaan menggunakan jasa KAP yang berafiliasi dengan KAP The Big Four Auditor maka diberikan kode 1. Sedangkan jika perusahaan menggunakan jasa KAP yang tidak berafiliasi dengan KAP The Big Four Auditor maka diberikan kode 0.

e. Audit tenure

Variabel audit tenure dihitung dengan menjumlah total panjang masa perikatan audit sebelum auditor (KAP) berpindah.

f. Biaya audit

Pengukuran biaya audit diukur dengan melihat perpindahan kelas KAP dari NonBig 4 ke Big 4 atau sebaliknya. Variabel biaya audit menggunakan variabel dummy. Jika klien melakukan change class atauperpindahan kelas Kantor Akuntan Publik (KAP) dari Big Four, maka diberikan kode 1. Sedangkan jika klien tidak melakukan perpindahan kelas (change class) Kantor Akuntan Publik (KAP) dari Big Four, maka diberikan kode 0. 


\section{Hasil penelitian}

\subsection{Analisis statistic deskriptif}

Tabel 1. Statistik deskriptif (descriptive statistic).

\begin{tabular}{llllll}
\hline & $\mathrm{N}$ & Minimum & Maximum & Mean & Std. Deviation \\
\hline KK & 156 & $-7,719540$ & 22,461097 & 1,39298681 & 3,014398781 \\
DEWAN & 156 & 0 & 1 &, 44 &, 497 \\
OPINI & 156 & 0 & 1 &, 36 &, 481 \\
BIG4 & 156 & 0 & 1 &, 19 &, 390 \\
TENURE & 156 & 1 & 5 & 2,01 & 1,041 \\
FEE & 156 & 0 & 1 &, 02 &, 138 \\
SWITCH & 156 & 0 & 1 &, 39 &, 490 \\
Valid N (listwise) & 156 & & & & \\
\hline
\end{tabular}

Sumber: Hasil olahan SPSS

Berdasarkan tabel 1 dapat diperjelas maknanya sebagai berikut:

- Jumlah seluruh sampel adalah 39 perusahaan dengan 156 unit analisis, yaitu 39 perusahaan dikali dengan empat tahun penelitian yaitu tahun 2011 sampai dengan 2014.

- Variabel kesulitan keuangan memiliki nilai minimum -7,719540, nilai maksimum 22,461097, mean (nilai ratarata) 1,39298681, dan Standart Deviation (simpangan baku) variabel ini adalah 3,014398781.

- Variabel pergantian dewan komisaris memiliki nilai minimum 0, nilai maksimum 1, mean (nilai rata-rata) 0,44 , dan Standart Deviation (simpangan baku) variabel ini adalah 0,497.

- Variabel opini audit memiliki nilai minimum 0, nilai maksimum 1, mean (nilai rata-rata) 0,36, dan Standart Deviation (simpangan baku) variabel ini adalah 0,481.

- Variabel reputasi auditor memiliki nilai minimum 0, nilai maksimum 1, mean (nilai rata-rata) 0,19, dan Standart Deviation (simpangan baku) variabel ini adalah 0,390 .

- Variabel audit tenure memiliki nilai minimum 1, nilai maksimum 5, mean (nilai rata-rata) 2,01, dan Standart Deviation (simpangan baku) variabel ini adalah 1,041 .

- Variabel biaya audit memiliki nilai minimum 0, nilai maksimum 1, mean (nilai rata-rata) 0,02, dan Standart Deviation (simpangan baku) variabel ini adalah 0,138 .

- Variabel Auditor Switching memiliki nilai minimum 0, nilai maksimum 1, mean (nilai rata-rata) 0,39, dan Standart Deviation (simpangan baku) variabel ini adalah 0,490.

\subsection{Analisis statistic deskriptif}

\subsubsection{Hasil pengujian hipotesis}

Tabel 2.Hasil uji overall fit model -2 Log Likelihood awal.

\section{Iteration History}

\begin{tabular}{llll}
\hline Iteration & & -2 Log Likelihood & Coefficients Constant \\
\hline Step 0 & 1 & 208,794 &,- 436 \\
& 2 & 208,792 &,- 443 \\
& 3 & 208,792 &,- 443 \\
\hline
\end{tabular}

Constant is included in the model.

b. Initial -2 Log Likelihood: 208,792 
c. Estimation terminated at iteration number 3 because parameter estimates changed by less than ,001. Sumber: Hasil Ouput SPSS

Tabel 3. Hasil uji overall fit model -2 Log Likelihood akhir.

\begin{tabular}{|c|c|c|}
\hline Iterasi & & -2 Log Likelihood \\
\hline \multirow[t]{20}{*}{ Step 1} & 1 & 96,183 \\
\hline & 2 & 56,916 \\
\hline & 3 & 37,693 \\
\hline & 4 & 31,097 \\
\hline & 5 & 29,560 \\
\hline & 6 & 29,361 \\
\hline & 7 & 29,353 \\
\hline & 8 & 29,352 \\
\hline & 9 & 29,351 \\
\hline & 10 & 29,351 \\
\hline & 11 & 29,351 \\
\hline & 12 & 29,351 \\
\hline & 13 & 29,351 \\
\hline & 14 & 29,351 \\
\hline & 15 & 29,351 \\
\hline & 16 & 29,351 \\
\hline & 17 & 29,351 \\
\hline & 18 & 29,351 \\
\hline & 19 & 29,351 \\
\hline & 20 & 29,351 \\
\hline
\end{tabular}

a. Method: Enter

b. Constant is included in the model.

c. Initial -2 Log Likelihood: 208,792

d. Estimation terminated at iteration number

20 because maximum iterations has been reached. Final solution cannot be found.

Sumber: Hasil Output SPSS

Berdasarkan tabel 2 dan tabel 3, diperoleh informasi bahwa pengujian dilakukan dengan membandingkan nilai antara -2 Log Likelihood (-2LL) awal (Block Number=0) dengan nilai -2 Log Likelihood (-2LL) akhir (Block Number=1). Nilai -2LL awal adalah 208,792. Setelah dimasukkan keenam variabel independen, maka nilai -2LL akhir mengalami penurunan menjadi 29,351. Penurunan -2 LogLikelihood ini menunjukkan model regresi yang lebih baik atau dengan kata lain model yang dihipotesiskan fit dengan data.

\subsubsection{Hasil uji kelayakan model regresi}

Tabel 4. Hasil uji Hosmer And Lemeshow's Goodness of Fit Test.

Hosmer and lemeshow test

\begin{tabular}{llll}
\hline Step & Chi-square & Df & Sig \\
\hline
\end{tabular}




\begin{tabular}{llll}
\hline 1 & 3,528 & 8 &, 897 \\
\hline Sumber: Hasil Output SPSS
\end{tabular}

Nilai statistik Hosmer and Lameshow"s Goodness of Fit Test lebih besar dari 0,05, maka berarti model mampu mempredisi nilai observasinya atau dapat dikatakan model dapat diterima karena cocok dengan data observasinya. Tabel4menunjukkan bahwa besarnya nilai statistik 0,897 dimana 0,897>0,05. Hal ini berarti model regresi yang dipergunakan dalam penelitian ini layak dipakai untuk analisis selanjutnya, karena tidak ada perbedaan yang nyata antara klasifikasi yang diprediksi dan klasifikasi yang diamati.

\subsubsection{Hasil uji koefisien determinasi (Negelkerke R. Square)}

Table 5. Hasil uji koefisien determinasi.

\section{Model summary}

\begin{tabular}{llll}
\hline Step & -2 Log Likelihood & Cox \& Snell R Square & Nagelkerke R Square \\
\hline 1 & 29,351 &, 683 &, 926 \\
\hline
\end{tabular}

Sumber: Hasil Output SPSS

Tabel 5 menunjukkan bahwa nilai Nagelkerke $R$ Square sebesar 0,926. Hal ini menunjukkan bahwa auditor switching pada perusahaan Manufaktur yang terdaftar di Bursa Efek Indonesia dipengaruhi oleh kesulitan keuangan, pergantian dewan komisaris, opini audit, reputasi auditor, audit tenure, dan biaya audit sebesar 92,6\%, sedangkan $7,4 \%$ sisanya dipengaruhi oleh faktor-faktor lain.

\subsubsection{Hasil uji hipotesis secara simultan}

Tabel 6. Hasil uji hipotesis secara simultan.

\begin{tabular}{lllll}
\multicolumn{2}{l}{ Omnibus Tests of Model Coefficients } \\
\multicolumn{1}{r}{} & Chi-square & Df & Sig \\
\hline Step 1 & Step & 179,441 & 6 &, 000 \\
& Block & 179,441 & 6 & 000 \\
& Model & 179,441 & 6 & 000 \\
\hline
\end{tabular}

Sumber: Hasil Output SPSS

Tabel 6 menunjukkan bahwa hasil signifikansi 0,000 lebih kecil dari $\alpha=0,05$. Hal ini menunjukkan bahwa semua variabel independen secara simultan berpengaruh terhadap auditor switching.

\subsection{Hasil uji regresi logistik}

Table 7. hasil uji koefisien regresi logistik.

Variables in the equation

\begin{tabular}{llllllll}
\hline & & B & S. E. & Wald & Df & Sig. & $\operatorname{Exp}(\mathrm{B})$ \\
\hline Step & KK &,- 035 &, 192 &, 033 & 1 &, 856 &, 966 \\
& DEWAN &, 630 & 1,201 &, 275 & 1 &, 600 & 1,877 \\
& OPINI & $-2,081$ & 1,256 & 2,746 & 1 &, 098 &, 125 \\
& BIG4 &,- 330 & 1,963 &, 028 & 1 &, 866 &, 719
\end{tabular}




\begin{tabular}{lllllll} 
TENURE & 7,20 & 1,458 & 24,403 & 1 &, 000 &, 001 \\
FEE & 18,383 & 22456,805 &, 000 & 1 &, 999 & 96264942,163 \\
Constant & 10,970 & 2,207 & 24,699 & 1 &, 000 & 58119,855 \\
\hline
\end{tabular}

Sumber: Hasil output SPSS

Dari hasil persamaan regresi logistik tersebut, maka diperoleh model regresi logistik sebagi berikut:

SWITCH=10,970-0,035KK+ 0,630DEWAN -2,081OPINI - 0,330BIG-7,201TENURE+ 18,383FEE

\section{Pembahasan hasil penelitian}

\subsection{Pengujian Hipotesis 1}

Kesulitan Keuangan mempunyai tingkat signifikansi 0,856 lebih besar dari tingkat signifikansi 0,05, sehingga variabel kesulitan keuangan tidak berpengaruh signifikan terhadap auditor switching.

\subsection{Pengujian Hipotesis 2}

Pergantian dewan komisaris mempunyai tingkat signifikansi 0,600 lebih besar dari tingkat signifikansi 0,05, sehingga variabel pergantian dewan komisaris tidak berpengaruh signifikan terhadap auditor switching.

\subsection{Pengujian Hipotesis 3}

Opini audit mempunyai tingkat signifikansi 0,098 lebih besar dari tingkat signifikansi 0,05 , sehingga variabel opini audit tidak berpengaruh signifikan terhadap auditor switching.

\subsection{Pengujian Hipotesis 4}

Reputasi Auditor mempunyai tingkat signifikansi 0,866 lebih besar dari tingkat signifikansi 0,05, sehingga variabel reputasi auditor tidak berpengaruh signifikan terhadap auditor switching.

\subsection{Pengujian Hipotesis 5}

Audit tenuremempunyai tingkat signifikansi 0,000 lebih kecil dari tingkat signifikansi 0,05, sehingga variabel pergantian audit tenure berpengaruh signifikan terhadap auditor switching.

\subsection{Pengujian Hipotesis 6}

Biaya audit mempunyai tingkat signifikansi 0,999 lebih besar dari tingkat signifikansi 0,05 , sehingga variabel biaya audit tidak berpengaruh signifikan terhadap auditor switching.

\subsection{Pengujian Hipotesis 7}

Berdasarkan hasil pengujian secara simultan, kesulitan keuangan, pergantian dewan komisaris, opini audit, reputasi auditor, audit tenure, biaya audit mempunyai tingkat signifikansi 0,000 lebih kecil dari tingkat signifikansi 0,05. Hal ini berarti seluruh variabel independen secara bersama-sama berpengaruh terhadap auditor switching.

\section{Kesimpulan}

Berdasarkan hasil pengujian dan pembahasan yang dijelaskan pada bagian sebelumnya, maka dapat disimpulkan bahwa:

- Kesulitan keuangan tidak berpengaruh terhadap auditor switching pada perusahaan manufaktur

- yang terdaftar di BEI periode 2011-2014, dengan nilai signifikansi 0,856.

- Pergantian dewan komisaris tidak berpengaruh terhadap auditor switching pada perusahaan manufaktur yang terdaftar di BEI periode 2011-2014, dengan nilai signifikansi 0,600. 
- Opini audit tidak berpengaruh terhadap auditor switching pada perusahaan manufaktur yang

- terdaftar di BEI periode 2011-2014, dengan nilai signifikansi 0,098.

- Reputasi auditor tidak berpengaruh terhadap auditor switching pada perusahaan manufaktur yang terdaftar di BEI periode 2011-2014, dengan nilai signifikansi 0,866.

- Audit tenure berpengaruh terhadap auditor switching pada perusahaan manufaktur yang terdaftar

- di BEI periode 2011-2014, dengan nilai signifikansi 0,000.

- Biaya audit tidak berpengaruh terhadap auditor switching pada perusahaan manufaktur yang terdaftar di BEI periode 2011-2014, dengan nilai signifikansi 0,999.

- Kesulitan keuangan, pergantian dewan komisaris, opini audit, reputasi auditor, audit tenure, biaya

- audit berpengaruh secara simultan terhadap auditor switching pada perusahaan manufaktur yang terdaftar di BEI periode 2011-2014, dengan nilai signifikansi 0,000.

\section{References}

[1] Arens, A. A., R. J. Elder, dan M.S. Beasley, 2008. Auditing dan Jasa Assurance: Pendekatan Terintegrasi, Edisi Kedua Belas, Erlangga, Jakarta.

[2] Aprillia, Ekka, 2013. "Analisis Faktor-Faktor Yang Mempengaruhi Auditor Switching”, Accounting Analysis Journal AAJ 2(2) (2013).

[3] Astrini, Novia Retno, 2013. "Analisis Faktor-Faktor Yang Mempengaruhi Perusahaan Melakukan Auditor switching Secara Voluntary", Diponegoro Journal Of accounting, Volume 2, Nomor 3, Hal 1-11.

[4] Chadegoni, A.A, Z. M. Mohammed dan A. Jari, 2011."The Determinant Factors Of Auditor Switch Among Companies Listed On Tehran Stock Exchange", International Research Journal Of Finance and Economics_issue 80 (2011).

[5] Chow, C.W. dan S. J. Rice, 1982. "Qualified Audit Opinions and Auditor Switching”, The Accounting Review. Vol. LVII No.2 : page $326-$ 335.

[6] Dwiyanti, R. Meike Erika, 2014. "Faktor-Faktor Yang Mempengaruhi Auditor Switching secara Voluntary", Skripsi, Fakultas Ekonomi dan Bisnis Universitas Diponegoro.

[7] Erlina, 2011.Metodologi Penelitian, USU Press, Medan.

[8] Ghozali, Imam, 2006. Aplikasi Analisis Multivariate dengan Program SPSS, Cetakan IV, Badan Penerbit Universitas Diponegoro, Semarang.

[9] Guy, D. M., C. W. Alderman dan A. J. Winters, 2002.Auditing, Edisi Kelima, Erlangga, Jakarta.

[10] Hudaib, Mohammad dan T.E Cooke.2005.Qualified Audit Opinion and Auditor Switching.Departement of Accounting and Finance Scholl of Business and Economics University of Exeter Streatham Court. UK.

[11] Hutabarat, Harry, 2013. "Analisis Pengaruh Ukuran Perusahaan Klien, Financial Distress, Opini Going Concern, dan Reputasi auditor terhadap Auditor Switching", Skripsi, Universitas Sumatera Utara. Jansen, Michael C dan Meckling W.H.1976.Theory of The Firm:Managerial Behavior, Agency Cost and Ownership Structure.Journal of Financial Economics 3. hal 305-360.

[12] Lubis, Ade Fatma, Arifin Akhmad, dan Firman Syarif, 2007. Aplikasi SPSS (Statistical Product and Service Solutions) untuk Penyusunan Skripsi dan Tesis, USU Press, Medan.

[13] Mahantara, A. A. Gede Widya, 2013. "Faktor-Faktor Yang Mempengaruhi Pergantian Kantor Akuntan Publik Pada Perusahaan Manufaktur Yang Terdaftar di Bursa Efek Indonesia", Tesis, Universitas Udayana.

[14] Menteri Keuangan, 2003. Keputusan Menteri Keuangan Nomor 359/ KMK 06/2003 tentang Jasa Akuntan Publik.www. Kemenkeu.go.id.

[15] Menteri Keuangan, 2003. Keputusan Menteri Keuangan Nomor: 17/PMK.01/2008 tentang Jasa Akuntan Publik.www. Kemenkeu.go.id.

[16] Nabila, 2011. "Faktor-Faktor Yang Mempengaruhi Auditor Switching", Skripsi, Fakultas Ekonomi Universitas Diponegoro.

[17] Nasser et al, 2006. "Auditor-Clients Relationship: The Case of Audit Tenure and Auditor Awitching in Malaysia", Managerial Auditing Journal Special Issue, Vol. 21 (7), PP.724-737.

[18] Nikmah, Latifatun, 2014. “Analisis Faktor-Faktor Yang Mempengaruhi Pergantian Auditor”, Diponegoro Journal Of Accounting, Volume 3, Nomor 3, Hal 1-14.

[19] Nurzaimah dan Syahrul Rambe, 2010.Akuntansi Keuangan Menengah I, USU Press, Medan.

[20] Olivia, 2014."Analisis Faktor-Faktor Yang Mempengaruhi Auditor Switching pada Perusahaan Manufaktur yang Terdaftar di BEI”, Skripsi, Universitas Hasanuddin.

[21] Pradipta, Randi Pujas, 2014. "Faktor-Faktor Yang Mempengaruhi Perusahaan Manufaktur Terdaftar di BEI melakukan pergantian Auditor Secara Voluntary",Diponegoro Journal Of Accounting, Volume 3, Nomor 3, Hal 1.

[22] Prahartari, F.A., 2013. "Analisis Faktor-faktor yang Mempengaruhi Auditor Switching”, Skripsi.Universitas Islam Negeri Syarif Hidayatullah.

[23] Putra, I Wayan Dewa Widia, 2014.”Pengaruh Financial Distress, Rentabilitas, Pertumbuhan Perusahaan dan Opini Audit pada Pergantian Auditor", E-journal Akuntansi Universitas Udayana. 
[24] Rahmawati, Filka, 2011. "Faktor-Faktor Yang Mempengaruhi Perusahaan Yang Terdaftar di BEI Melakukan Pergantian Kantor Akuntan Publik", Jurnal Ekonomi dan Bisnis.

[25] Schwartz, K.B. dan B.S. Soo. 1995. An Analysis of Firm 8-K Disclousure of Auditor Changes by Firms Approaching Bankruptcy, Auditing: A Journal of Practice Theory, Vol. 14. No. 1, Spring 1995, 125-135.

[26] Sembiring, Prima Suranta, 2015. "Analisis Faktor-Faktor Yang Mempengaruhi Terjadinya Pergantin Kantor Akuntan Publik (Auditor Switching) pada Perusahaan Makanan dan Minuman (Food and Beverages) Yang Terdaftar di Bursa Efek Indonesia", Skripsi, Universitas Sumatera Utara.

[27] Sihombing, M.M., 2012. “Analisis Hubungan Auditor-Klien: Faktor-Faktor Yang Mempengaruhi Auditor Switching”, Jurnal Ekonomi dan Bisnis.

[28] Sinarwati, Ni Kadek, 2010. "Mengapa Perusahaan Manufaktur Yang Terdaftar Di BEI Melakukan Pergantian Kantor Akuntan Publik?", Simposium Nasional Akuntansi XIII: 1-20.

[29] Susan dan Estralita Trisnawati, 2011. "Faktor-Faktor Yang Mempengaruhi Perusahaan Melakukan Auditor Switch", Jurnal Bisnis dan Akuntansi, Vol 13, No.2, Hlm 131-144.

[30] Tate, Stepanie L., 2007. “Auditor Change and Auditor Choice in Nonprofit Organizations”, Auditing : A Journal Of Practice and Theory, Vol.26, no.1, pp.47-70.

[31] Wijayani, Evy Dwi, 2011. Analisis Faktor-Faktor Yang Mempengaruhi Perusahaan di Indonesia Melakukan Auditor Switching”, Skripsi. Universitas Diponegoro.

[32] Wijayanti, Martina Putri, 2010. "Analisis Hubungan Auditor- Klien: Faktor-Faktor Yang Mempengaruhi Auditor Switching di Indonesia", Skripsi. Universitas Diponegoro. wikipedia.org (Diakses pada 3 November 2015)

[33] www.idx.co.id (Diakses pada 3 November 2015)

[34] www.sahamok.com (Diakses pada 3 November 2015) 